\title{
Is the Revised Bloom's Taxonomy Revisited in the EFL/ESL Reading Textbooks?
}

\section{Ömer Gökhan Ulum ${ }^{1}$}

${ }^{1}$ Assoc. Prof., Mersin University, Mersin/Turkey ORCID: 0000-0001-7685-6356

E-Mail: omergokhanulum@gmail.com

Corresponding Author: Ömer Gökhan Ulum

January 2022

Volume:19

Issue: 45

DOI: $10.26466 / /$ opusjsr.1062878

Ulum, Ö.G. (2022). Is the revised Bloom's Taxonomy revisited in the EFL/ESL reading textbooks? . OPUS- Journal of Society Research, 19(45), 170-177.

\begin{abstract}
Benjamin Bloom and his colleagues produced a cognitive model for classifying educational objectives. This model has not been properly utilized by teachers and university instructors in their teaching settings. This cognitive model covers six main levels as knowledge, comprehension, application, analysis, synthesis, and evaluation which, after knowledge, were displayed as skills and abilities, with the fact that knowledge was the essential prerequisite for putting these skills and abilities into practice. In the taxonomy, each category bears a continuum from concrete to abstract and simple to complex. In 2001, a group of cognitive psychologist revisited and modernized Bloom's Taxonomy for teaching, learning, and assessment. Accordingly, the revised Bloom's taxonomy drew attention away from the partially passive image of educational objectives and hints on a more active conception of categorization. The revised taxonomy employs verbs and gerunds to refer to cognitive levels unlike the nouns employed in the original taxonomy. The dynamic words in the revised taxonomy define the cognitive processes through which thinkers confront and work with knowledge. The learning goals are significant to form a pedagogical interchange in order that learners and instructors perceive the aim of that interchange. Having and classifying objectives support teachers in planning and supplying quality education, forming proper assessment tasks, and ensuring teaching to go parallel with the objectives. Hence, this research paper hints on investigating to what extent the revised Bloom's taxonomy is employed in the reading comprehension questions of an EFL reading textbook. Thus, two research questions were developed to find out the state of cognitive skills stated in the revised taxonomy, the first question aiming at evaluating the lower level while the second one involving the higher cognition level. The investigated EFL reading textbook was analyzed through descriptive content analysis. The findings of the study showed that the examined textbook lacked the higher level cognitive skills highlighted in the revised version of the taxonomy. Related assumptions have been accordingly provided to recommend how the reading textbooks which are being written or will be written should be integrated with the revised Bloom's taxonomy when assessing reading skills.
\end{abstract}

Key Words: Cognitive Skills, Cognitive Domain, Taxonomy, The Revised Bloom's Taxonomy, Reading Comprehension, Reading Assessment.

\section{$\ddot{O} z$}

Benjamin Bloom ve meslektaşları, eğitim hedeflerini smuflandırmak için bilişsel bir model üretti. Bu model, öğretmenler ve üniversite öğretim görevlileri tarafından öğretim ortamlarında gerektiği gibi kullanılmamıştı. Bu bilişsel model bilgi, kavrama, uygulama, analiz, sentez ve değerlendirme olmak üzere altı ana düzeyi kapsar ve bilgiden sonra beceri ve yetenekler olarak sergilenirken, bilginin bu beceri ve yetenekleri uygulamaya koymann temel ön koşulu olduğu bir gerçektir. Taksonomide, her kategori somuttan soyuta ve basitten karmaşı̆̆a bir süreklilik taşır. 2001'de bir grup bilişsel psikolog, öğretme, öğrenme ve değerlendirme için Bloom'un Taksonomisini yeniden gözden geçirdi ve modernize etti. Buna göre, revize edilmiş Bloom taksonomisi, dikkatleri eğitim hedeflerinin kısmen pasif görüntüsünden uzaklaștırdı ve daha aktif bir sinıflama anlayısıına dair ipuçları verdi. Gözden geçirilmiș taksonomi, orijinal taksonomide kullanılan isimlerden farkl olarak bilişsel seviyelere atıfta bulunmak için filler ve ulaçlar kullandı. Gözden geçirilmiş taksonomideki dinamik kelimeler, düşünürlerin bilgiyle yüzleştiği ve bilgiyle çalıştı̆̆ bilişsel süreçleri tanımlar. Öğrenme hedefleri, öğrencilerin ve öğretmenlerin bu değişimin amacın algılaması için ve pedagojik bir değişim oluşturmak için önemlidir. Hedeflere sahip olmak ve bunlar sinfflandırmak, öğretmenleri kaliteli eğitimin planlanması ve să̆lanmasında, uygun değerlendirme görevlerinin oluşturulmasında ve öğretimin hedeflerle paralel gitmesini sağlamada fayda sağlar. Bu nedenle, bu araştırma makalesi, bir İngilizce okuma ders kitabının okuduğunu anlama sorularında yenilenmiş Bloom taksonomisinin ne ölçüde kullanıldığın araştırmaya yönelik ipuçları vermektedir. Yenilenmiş taksonomide belirtilen bilişsel becerilerin durumunu ortaya çıkarmak için iki araştırma sorusu geliştirilmiştir. Birinci araştırma sorusu alt düzey bilişsel becerileri kapsarken, ikincisi ise üst düzey bilişsel becerileri kapsamaktadır. İncelenen İngilizce okuma kitabı betimsel içerik analizi yoluyla analiz edilmiştir. Çalışmanın bulgularn, incelenen ders kitabının, taksonominin yenilenmiş versiyonunda vurgulanan üst düzey bilişsel becerilerden yoksun olduğunu göstermiştir. Buna bağh olarak, okuma becerilerini değerlendirirken, yazılmakta olan veya yazlacak olan okuma kitaplarmın yenilenmiş Bloom taksonomisi ile nasıl entegre edilmesi gerektiği konusunda tavsiyelerde bulunulmuştur.

Anahtar Kelimeler: Bilişsel Beceriler, Bilişsel Alan, Taksonomi, Yenilenmiş Bloom Taksonomisi,

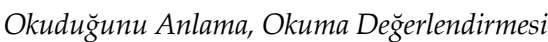




\section{Introduction}

Bloom's Taxonomy is the most widely accepted model of systematic classification of the learning outcomes of the curriculum, as well as assessment (Adams, 2015). It was produced by Bloom in 1956 according to a certain hierarchical structure and complexity (Furst, 1981). However, due to the change in the perspective of today's society on information and how information is obtained, it was needed to be renewed (Forehand, 2010). It was revised by Anderson and Kratwhohl (2001) and took its final version accordingly. The revised Bloom's taxonomy reconsiders the structure of the original taxonomy that has been criticized for years (Krathwohl \& Anderson, 2010). Thus, it has become an important planning tool in the field of education programs and teaching, in which contemporary developments are tried to be reflected (Krathwohl, 2002). In the revised taxonomy, there has been a transition from one dimension to two dimensions, the cognitive process dimension and the knowledge dimension (Huitt, 2011). Making it two-dimensional and visual has made significant contributions to the field of curriculum development (Bümen, 2007). Knowledge dimension steps help teachers decide what to teach students. The sub-levels of the knowledge dimension consist of four dimensions: factual knowledge, conceptual knowledge, procedural knowledge and metacognitive knowledge (Darwazeh, 2017). Factual knowledge is defined as the basic knowledge that a student must know to solve problems in a subject area (Su, Osisek, \& Starnes, 2004). Conceptual knowledge, on the other hand, is considered as the relations between the basic elements of a large structure and which enable the elements that make up this structure to act together (Jideani \& Jideani, 2012). Procedural knowledge is defined as criteria for how to do operate research methods, skills, algorithms, techniques and methods (Lee, Kim, \& Yoon, 2015). Meta-relational knowledge, which is one of the knowledge dimension steps, means that the person is aware of and has knowledge about his own cognition (Anderson and Krathwohl, 2010). According to the constructivist approach, cognitive process dimension steps help students to actively participate in learning through asking such questions "How is teaching provided?", "How does the student learn meaningfully?" (Phillips, Smith, Straus, 2013). The cognitive process dimension consists of six sub-dimensions: remembering, understanding, applying, analyzing, evaluating and creating (Radmehr \& Drake, 2017). The recall step is defined as accessing relevant information in long-term memory (Wei \& Ou, 2019). Comprehension step is considered as creating meaning from the messages from teaching process, which can be in oral, written or graphic forms (Churches, 2008). The implementation step is defined as executing or using the process path (Waite, Zupec, Quinn, \& Poon, 2020). The analysis step, on the other hand, is defined as dividing the material into its constituent parts and determining the relations of the parts with each other and with the whole material (Susan, Warsono, \& Faridi, 2020). While there are judgments based on the criteria and standards in the evaluation step, the creation step is based on creating a new, original product by bringing the elements together in a harmonious manner (Anderson and Krathwohl, 2010). Evaluation is as important as teaching and learning in curricula. In order to make the evaluation easier for the practitioners, a classification was made by Bloom (1956) to determine the knowledge and skill levels of the students. Bloom developed taxonomy for alternative evaluation alongside traditional evaluation (Febrina, Usman, \& Muslem, 2019). Cognitive steps of Bloom's taxonomy can be expressed as knowledge, comprehension, application, analysis, synthesis and evaluation. The original Bloom's taxonomy has been renewed to keep up with today's information age. The cognitive steps of the renewed Bloom Taxonomy has taken its place in the education system again as remembering, understanding, applying, analyzing, evaluating and creating (Abdelrahman, 2014). In this renewed taxonomy, the strict hierarchical order has been demolished and a slightly more flexible taxonomy has been 
introduced. With this change, it became easier to write a goal and it was able to take place in the evaluation process in the performance evaluation. Among the reasons for the renewal of the Bloom's taxonomy are the renewal of the programs, the constructivist approach to learning, the onedimensional analysis of the old Bloom's taxonomy and its inability to measure high-level skills (Larkin \& Burton, 2008). It has been suggested by Anderson and Krathwohl that instead of examining the acquisitions in a complex one-dimensional way, they should be organized in a way to measure two-dimensional and high-level skills. Based on this, it was predicted that examining the target acquisitions in knowledge and cognitive dimensions would be more beneficial and a more effective evaluation could be made (Anderson \& Krathwohl, 2001). It was stated that the picture that emerged with the renewed Bloom taxonomy will provide convenience to the practitioners in the planning of the teaching and the evaluation of the process (Halawi, McCarthy, \& Pires, 2009). During the revision process, the editors identified 19 alternative schemes to supplement, clarify, and enhance the original Bloom's taxonomy. They examined alternative schemas that could contribute to the updated taxonomy. Of these, 8 represented two or more dimensions as the revised Bloom taxonomy, while 11 represented a single dimension, such as the original taxonomy. Two reasons are suggested for the renewal (Betts, 2008). The first one is to try to get educators to refocus on the original taxonomy. The second reason is that the developments in the USA and the world since 1956, the development and learning psychology, teaching methods and techniques, and contemporary information about measurement and evaluation need to be combined with this taxonomy which may have a greater impact internationally (Assaly \& Smadi, 2015; Case, 2013). In many countries around the world, taxonomy has been used as the basis for curriculum development, test creation, lesson planning, and teacher training (Adams, 2015; Krathwohl,2009).

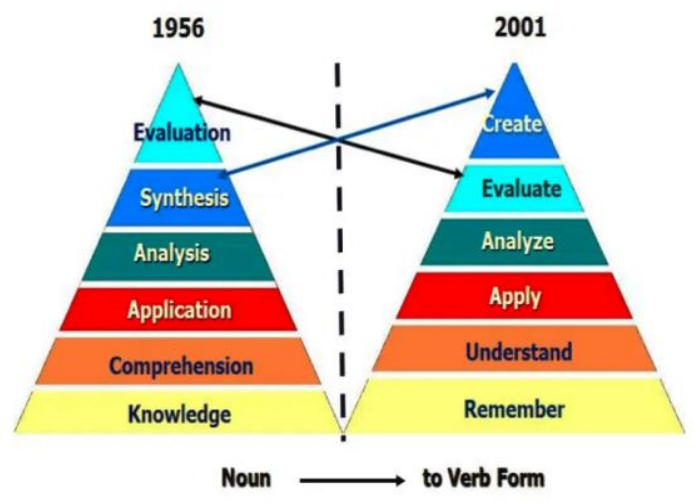

Figure 1. Bloom's Taxonomy Revised (Wilson, 2001)

Therefore, this study is based on investigating to what extent the revised Bloom's taxonomy is utilized in the reading comprehension questions of an EFL reading textbook.

\section{Purpose of the Study}

This study addresses the extent of the cognitive levels of the revised Bloom's taxonomy involved in the reading comprehension questions of a globally written EFL reading course book. Similarly, this study focuses on interpreting whether any weaknesses or strengths are present in the reading comprehension questions or not, in terms of covering both the lower and higher order cognitive thinking skills underlined by the revised Bloom's taxonomy. Accordingly, the following research questions were put forward:

1. To what extent do the reading comprehension questions in the EFL Reading course book Focus on Reading 2 contain the lower order cognitive levels stated by the revised Bloom's taxonomy?

2. To what extent do the reading comprehension questions in the EFL Reading course book Focus on Reading 2 contain the higher order cognitive levels stated by the revised Bloom's taxonomy?

\section{Significance of the Study}

The reading comprehension questions employed in the present EFL reading course book are evaluated in this study. The study also focuses on interpreting the frequency of both lower and higher order cognition levels emphasized by the 
revised Bloom's Taxonomy. The ways that may support course book writers in producing high quality course books are accordingly provided in the study. Besides, the results of the paper will be of great importance for reading instructors to be competent in preparing reading comprehension questions based on the revised Bloom's Taxonomy.

\section{Limitations of the Study}

EFL/ESL settings, besides the common education, should refer to lower and higher order cognitive domains stated by the revised Bloom's taxonomy to provide learners with the demanded cognitive skills (Assaly \& Smadi, 2015). The revised Bloom's Taxonomy was chosen to evaluate the reading comprehension questions of a reading course book utilized in EFL/ESL settings, which means that this study is limited to solely an EFL reading course book. The data gathered in this research paper did not include other EFL/ESL reading course books.

\section{Methodology}

This research paper is based on a descriptive content analysis approach to interpret the frequency of the high and low order cognitive steps underlined in the revised Bloom's taxonomy. Similarly, the cognitive skills stated in the revised Bloom's taxonomy were administered while categorizing the reading comprehension questions of an EFL reading comprehension course book. The frequencies of every cognitive step, percentages, and examples of reading questions are shown below. Firstly, with the aim of answering the research question of the study, key words referring to the cognitive levels of the revised Bloom's taxonomy and question stems based on the cognitive domains were utilized to discover which cognitive steps were included in the assessed reading questions. The textbook inquired in this research study is Focus on Reading 3 which was written by Gillian Flaherty and Chris Coey and published by Nüans Publishing. This study is based on a qualitative research design, since it made use of percentages, frequencies, and examples from the reading comprehension questions were supplied in the study. As the revised Bloom's taxonomy is a highly useful framework for examining the education materials (Zareian, Davoudi, Heshmatifar, \& Rahimi, 2015), in order to evaluate the reading comprehension questions with respect to the cognitive domains, a descriptive content analysis method was used through collecting, classifying, and investigating the reading questions according to low and high order cognitive skills. Consequently, the theoretical framework of this inquiry is the revised Bloom's taxonomy and the findings were tabulated accordingly.

\section{Data Analysis and Results}

The data analysis of the study is comprised of sorting the reading questions according to the six cognitive steps and two domains of low and high order framed in the revised Bloom's taxonomy. The corresponding rates are displayed as percentages and frequencies and the associated samples illuminating the levels of taxonomy are denoted below. In a similar way, the following tables $(1,2,3)$ and their related interpretations portray the mentioned aspects.

Bloom's Taxonomy in the Reading Questions

\begin{tabular}{lll}
\multicolumn{3}{l}{ Table 1.The Rate of the Six Cognitive Steps of the Revised } \\
\hline Level of question & f & \% \\
\hline Remember & 322 & 100.00 \\
Understand & - & - \\
Apply & - & - \\
Analyze & - & - \\
Evaluate & - & - \\
Create & - & - \\
Total & 322 & 100.00
\end{tabular}

Table 1 simply represents that remembering step $(100.00 \%)$ of the low cognitive domain is the solely emerging level. Similarly, while no occurrence was detected in the high cognitive domain which is comprised of analyzing, evaluating, and creating, only remembering step was observed in the low cognitive domain which involves remembering, understanding, and applying steps. The samples below exemplify the reading questions included in the assessment: 
- Where did the king keep his armies? (remembering level, unit 3, p.19)

- Circle T for true or F for false for each of the following statements. (remembering level, unit 7, p.34)

1. 1. Naomi Campell and Kate Moss are supermodels. $\quad \mathrm{T} / \mathrm{F}$

2. There are many famous male models. $\mathrm{T} / \mathrm{F}$

3. Travis Fimmel is Australian. $\mathrm{T} / \mathrm{F}$

4. 4. Male models can earn as much money as female models. $\quad \mathrm{T} / \mathrm{F}$

- How many Academy Awards has Rick Baker won? (remembering level, unit 8, p.38)

Revised Bloom's Taxonomy in the Reading Questions

Table 2. The Rate of the Higher and Lower Cognitive Domains of the

\begin{tabular}{lll}
\hline Level of question & $\mathbf{f}$ & $\%$ \\
\hline Lower Level & 322 & 100.00 \\
Higher Level & - & - \\
Total & 322 & 100.00 \\
\hline
\end{tabular}

One can clearly perceive from Table 2 that the lower cognitive domain is observed to have a percentage of 100.00 . On the other hand, the higher cognitive domain is detected to have no emergence in the overall reading comprehension course book.

Table 3. The Extent of the Remembering Level and Other Levels in Each Unit

\begin{tabular}{lllll}
\hline & \multicolumn{2}{l}{ Remembering } & \multicolumn{2}{l}{ Others } \\
Unit & $\mathrm{f}$ & $\%$ & $\mathrm{f}$ & $\%$ \\
\hline $\mathbf{1}$ & 16 & 100.00 & - & - \\
$\mathbf{2}$ & 16 & 100.00 & - & - \\
$\mathbf{3}$ & 18 & 100.00 & - & - \\
$\mathbf{4}$ & 16 & 100.00 & - & - \\
$\mathbf{5}$ & 16 & 100.00 & - & - \\
$\mathbf{6}$ & 16 & 100.00 & - & - \\
$\mathbf{7}$ & 16 & 100.00 & - & - \\
$\mathbf{8}$ & 16 & 100.00 & - & - \\
$\mathbf{9}$ & 16 & 100.00 & - & - \\
$\mathbf{1 0}$ & 16 & 100.00 & - & - \\
$\mathbf{1 1}$ & 16 & 100.00 & - & - \\
$\mathbf{1 2}$ & 16 & 100.00 & - & - \\
$\mathbf{1 3}$ & 16 & 100.00 & - & - \\
$\mathbf{1 4}$ & 16 & 100.00 & - & - \\
$\mathbf{1 5}$ & 16 & 100.00 & - & - \\
$\mathbf{1 6}$ & 16 & 100.00 & - & - \\
$\mathbf{1 7}$ & 16 & 100.00 & - & - \\
$\mathbf{1 8}$ & 16 & 100.00 & - & - \\
$\mathbf{1 9}$ & 16 & 100.00 & - & - \\
$\mathbf{2 0}$ & 16 & 100.00 & - & - \\
\hline
\end{tabular}

As it is evident in Table 3, the remembering step (100.00) is the only occurring cognitive level in each unit of the reading comprehension course book. However, no emergence has been observed in the understanding and applying steps of the low order cognitive domain, as well as in the analyzing, evaluating, and creating steps of the high order cognitive domain. In a similar vein, it is clearly understood from the table that, let alone the higher cognitive skills, the reading course book does not include the upper steps of the lower cognitive thinking domain.

\section{Discussion and Conclusion}

The aim of this study is analyze the revised Bloom's taxonomy in EFL/ESL course books (also see Köksal \& Ulum, 2018; Ulum, 2021). The findings show that the course books ignored lower cognitive skills in reading questions (Eason et al., 2012). However, higher cognitive domains were not addressed. The dimensions of analyzing, evaluating and creating were not mentioned in the reading questions (Rupp, Ferne, \& Choi, 2006). However, the dimensions of remembering, understanding and applying were only partially emphasized. The reading questions in the course books analyzed disregarded the sub-dimensions of categorizing, breaking down, classifying and organizing in the dimension of analyzing that also entailed distinguishing, structuring and integrating (Assaly \& Smadi, 2015). Integrated skills were not mentioned at all (Cumming, 2013). In addition, meaning negotiating was hardly broached (Schubauer-Leoni \& Grossen, 1993). Explaining an idea or event was another subdimension that was ignored in the course books and their reading questions (San, 2019).

Another dimension in higher cognitive domains was evaluating that included arguing, validating, assessing and debating (Liu, Frankel, \& Roohr, 2014). The reading questions did not lead the learners to discuss or debate certain issues. Predicting and reflecting were also other sub-dimensions that were disregarded in the reading questions. The questions did not contribute to their hypothesizing potential (Elder 
\& Paul, 2004; Paul \& Elder, 2004). Creating was another dimension in the revised Bloom's taxonomy and involved collaborating, composing, role-playing and simulating. These sub-dimensions were neglected in the reading questions (Ollmann, 1996). Thus, it can be interpreted that the sub-dimensions of analyzing, evaluating and creating were not emphasized and taken into consideration (Ulum \& Taşkaya, 2019). The dimension of creating in particular was the most ignored category in the reading questions (Walsh \& Hodge, 2018). Therefore, it is possible that second and foreign language learners cannot develop their critical thinking skills if higher cognitive skills cannot be endorsed in course books (Xu, 2011).

The studies that will be conducted in the field of second language education in the future should take the revised Bloom's taxonomy into consideration. English language teaching departments and other related departments and institutions should prepare English course books in line with the framework of the revised Bloom's taxonomy. Teachers should prepare additional tasks in order to feed students at a higher level. The following points can be recommended to address higher cognitive skills:

- Course books ought to deal with higher cognitive domains in reading questions and other skills.

- English language teaching departments should include classes regarding Bloom's taxonomy and enable teacher candidates to take the revised Bloom's taxonomy into account.

- Practitioners in the field should receive inservice training regarding the implementation of the revised Bloom's taxonomy

- Reading questions should be integrated together with other receptive and productive skills.

- Teacher candidates should be aware of these higher cognitive domains while teaching reading skills.
Abdelrahman, M. S. H. B. (2014). An analysis of the tenth grade English language textbooks questions in Jordan based on the revised edition of Bloom's taxonomy. Journal of Education and Practice, 5(18), 139-151.

Adams, N. E. (2015). Bloom's taxonomy of cognitive learning objectives. Journal of the Medical Library Association: JMLA, 103(3), 152.

Anderson, L. W. \& Krathwohl, D. R., et al (Eds..). (2001). A taxonomy for learning, teaching, and assessing: A revision of bloom's taxonomy of educational objectives. Boston: Allyn \& Bacon MA (Pearson Education Group)

Assaly, I. R., \& Smadi, O. M. (2015). Using Bloom's Taxonomy to evaluate the cognitive levels of master class textbook's questions. English Language Teaching, 8(5), 100-110.

Betts, S. C. (2008). Teaching and assessing basic concepts to advanced applications: Using Bloom's taxonomy to inform graduate course design. Academy of Educational Leadership Journal, 12(3), 99.

Case, R. (2013). The unfortunate consequences of bloom's taxonomy. Social Education, 77(4), 196-200.

Churches, A. (2008). Bloom's taxonomy blooms digitally. Tech \& Learning, 1, 1-6.

Cumming, A. (2013). Assessing integrated skills. The companion to language assessment. Abilities, Contexts, and Learners, 1, 216-229.

Darwazeh, A. N. (2017). A new revision of the [revised] Bloom's Taxonomy. Distance Learning, 14(3), 13-28.

Eason, S. H., Goldberg, L. F., Young, K. M., Geist, M. C., \& Cutting, L. E. (2012). Reader-text interactions: How differential text and question types influence cognitive skills needed for reading comprehension. Journal of educational psychology, 104(3), 515.

Elder, L., \& Paul, R. (2004). Critical Thinking and the Art of Close Reading (Part II). Journal of Developmental Education, 27(3), 36-37.

Febrina, F., Usman, B., \& Muslem, A. (2019). Analysis of reading comprehension questions by using revised Bloom's Taxonomy on Higher Order Thinking Skill (HOTS). English Education Journal, 10(1), 115.

\section{References}


Forehand, M. (2010). Bloom's taxonomy. Emerging perspectives on learning, teaching, and technology, 41(4), 47-56. Retrieved on the $30^{\text {th }}$ of August, 2021 from https://www.d41.org/cms/lib/IL01904672/Centri city/Domain/422/BloomsTaxonomy.pdf

Furst, E. J. (1981). Bloom's taxonomy of educational objectives for the cognitive domain: Philosophical and educational issues. Review of Educational Research, 51(4), 441-453.

Halawi, L. A., McCarthy, R. V., \& Pires, S. (2009). An evaluation of e-learning on the basis of Bloom's taxonomy: An exploratory study. Journal of Education for Business, 84(6), 374380.

Huitt, W. (2011). Bloom et al.'s taxonomy of the cognitive domain. Educational psychology interactive, 22.

Jideani, V. A., \& Jideani, I. A. (2012). Alignment of assessment objectives with instructional objectives using revised Bloom's taxonomy-The case for food science and technology education. Journal of Food Science Education, 11(3), 34-42.

Köksal, D., \& Ulum, Ö. G. (2018). Language assessment through Bloom's Taxonomy. Journal of language and linguistic studies, 14(2), 76-88.

Krathwohl, D. R. (2002). A revision of Bloom's taxonomy: An overview. Theory into practice, 41(4), 212-218.

Krathwohl, D. R. (2009). A revision of Bloom's taxonomy: An overview. Ilköğretim Online, 8(3), 1-7.

Krathwohl, D. R., \& Anderson, L. W. (2010). Merlin C. Wittrock and the revision of Bloom's taxonomy. Educational psychologist, 45(1), 6465.

Larkin, B. G., \& Burton, K. J. (2008). Evaluating a case study using Bloom's taxonomy of education. Aorn Journal, 88(3), 390-402.

Lee, Y. J., Kim, M., \& Yoon, H. G. (2015). The intellectual demands of the intended primary science curriculum in Korea and Singapore: An analysis based on revised Bloom's taxonomy. International Journal of Science Education, 37(13), 2193-2213.

Liu, O. L., Frankel, L., \& Roohr, K. C. (2014). Assessing critical thinking in higher education: Current state and directions for next-generation assessment. ETS Research Report Series, 2014(1), 1-23.

Ollmann, H. E. (1996). Creating higher level thinking with reading response. Journal of Adolescent $\mathcal{E}$ Adult Literacy, 39(7), 576-581.

Paul, R., \& Elder, L. (2004). Critical Thinking... and the Art of Close Reading, Part III. Journal of Developmental Education, 28(1), 36-37.

Phillips, A. W., Smith, S. G., \& Straus, C. M. (2013). Driving deeper learning by assessment: an adaptation of the Revised Bloom's Taxonomy for medical imaging in gross anatomy. Academic radiology, 20(6), 784-789.

Radmehr, F., \& Drake, M. (2017). Revised Bloom's taxonomy and integral calculus: unpacking the knowledge dimension. International Journal of Mathematical Education in Science and Technology, 48(8), 1206-1224.

Rupp, A. A., Ferne, T., \& Choi, H. (2006). How assessing reading comprehension with multiple-choice questions shapes the construct: A cognitive processing perspective. Language testing, 23(4), 441-474.

Schubauer-Leoni, M. L., \& Grossen, M. (1993). Negotiating the meaning of questions in didactic and experimental contracts. European Journal of Psychology of Education, 8(4), 451-471.

Su, W. M., Osisek, P. J., \& Starnes, B. (2004). Applying the Revised Bloom's Taxonomy to a medical-surgical nursing lesson. Nurse Educator, 29(3), 116-120.

San, K. M. (2019). The thinking levels demanded in reading activities in the coursebook global A2+. International Journal of Education and Research, 7(5), 23-36.

Susan, S., Warsono, W., \& Faridi, A. (2020). The evaluation of exercises compatibility between revised Bloom's taxonomy and 2013 curriculum reflected in English textbook. English Education Journal, 10(2), 252-265.

Ulum, Ö. G. (2016). A descriptive content analysis of the extent of Bloom's Taxonomy in the reading comprehension questions of the course book Q: skills for success 4 reading and writing. Qualitative Report, 21(9), 16741683.

Ulum, Ö. G. (2021). A critical approach to the inclusion of the revised Bloom's Taxonomy in active skills for reading: Book 1. RumeliDE 
Dil ve Edebiyat Araştırmaları Dergisi, 25, 273296.

Ulum, H., \& Taşkaya, S. M. (2019). Evaluation of the Activities in the Turkish Coursebooks (Student's Books and Workbooks) Used at the 2nd, 3rd, And 4th Classes of State Primary Schools According to Revised Bloom's Taxonomy. Kastamonu Education Journal, 27(1), 107-118.

Waite, L. H., Zupec, J. F., Quinn, D. H., \& Poon, C. Y. (2020). Revised Bloom's taxonomy as a mentoring framework for successful promotion. Currents in Pharmacy Teaching and Learning, 12(11), 1379-1382.

Walsh, R. L., \& Hodge, K. A. (2018). Are we asking the right questions? An analysis of research on the effect of teachers' questioning on children's language during shared book reading with young children. Journal of Early Childhood Literacy, 18(2), 264-294.

Wei, B., \& Ou, Y. (2019). A comparative analysis of junior high school science curriculum standards in Mainland China, Taiwan, Hong Kong, and Macao: Based on revised Bloom's taxonomy. International Journal of Science and Mathematics Education, 17(8), 1459-1474.

Wilson, L. O. (2001). Bloom's Taxonomy Revised. Retrieved on the $24^{\text {th }}$ of June, 2021 from https://thesecondprinciple.com/essentialteaching-skills/blooms-taxonomy-revised/

$\mathrm{Xu}, \mathrm{J}$. (2011). The application of critical thinking in teaching English reading. Theory and Practice in Language Studies, 1(2), 136-141.

Zareian, G., Davoudi, M., Heshmatifar, Z., \& Rahimi, J. (2015). An evaluation of questions in two ESP course books based on Bloom's new taxonomy of cognitive learning domain. International Journal of Education and Research, 3(8), 313-326. 